\title{
Jolanta Pakulska
}

Uniwersytet Kardynała Stefana Wyszyńskiego w Warszawie

e-mail: jolanta.pakulska@gmail.com

\section{WSKAŹNIKI INNOWACJI EKOLOGICZNYCH DLA POLSKI W LATACH 2010-2017}

\section{INDICATORS OF ECO-INNOVATIONS IN POLAND IN THE YEARS 2010-2017}

DOI: $10.15611 /$ pn.2018.532.23

JEL Classification: O11, O39, O57

\begin{abstract}
Streszczenie: Celem artykułu jest analiza pozycji Polski w zakresie innowacyjności ekologicznej na tle krajów członkowskich Unii Europejskiej w latach 2010-2017, a także analiza wskaźników składających się na wskaźnik syntetyczny dla naszego kraju. W opracowaniu zastosowano metodę opisową, a także analizę dynamiki zmian w czasie 16 wskaźników składających się na syntetyczny wskaźnik ekoinnowacyjności Polski. Analiza wykazała, że zdecydowana większość obszarów wymaga intensywnych działań na rzecz poprawy pozycji naszego kraju w rankingu Eco-IS.
\end{abstract}

Slowa kluczowe: innowacje ekologiczne, Eco-Innovation Index, nakłady na ekoinnowacje, działania, wyniki, efekty środowiskowe, efekty społeczno-gospodarcze.

Summary: The aim of the article is to analyze the position of Poland in the scope of ecological innovation in comparison to the EU member states, as well as to analyze the indicators composing the synthetic indicator for our country. In the study, a descriptive method was used as well as an analysis of the dynamics of changes over time in 16 indicators comprising a synthetic indicator of Poland's eco-innovativeness. The analysis has shown that the vast majority of areas require intensive efforts to improve the position of our country in the Eco-IS ranking.

Keywords: eco-innovation, Eco-Innovation Index, eco-innovation inputs, eco-innovation activities, eco-innovation outputs, resource efficiency outcomes, socio-economic outcomes.

\section{Wstęp}

Innowacje są siłą napędzającą gospodarkę, na co zwrócił uwagę już na początku ubiegłego wieku klasyk teorii rozwoju gospodarczego J. Schumpeter, który jest także twórcą teorii innowacji. Uważał on, że innowacje są podstawowym czynnikiem rozwoju gospodarczego. Innowacja w jego ujęciu jest to nowy lub udoskonalony wyrób albo metoda produkcji, nowe rynki, nowa metoda sprzedaży lub zakupów, 
nowe surowce lub półfabrykaty czy też nowa organizacja produkcji [Schumpeter 1960].

Na rolę innowacji ekologicznych zaczęto wskazywać dopiero w latach 90. XX w., gdy zauważono, że mogą być one skutecznym sposobem na zahamowanie narastających zagrożeń środowiska bez ograniczenia możliwości rozwoju gospodarczego. Innowacje ekologiczne są to takie innowacje, które są korzystne dla środowiska czy też redukują negatywne oddziaływanie działalności gospodarczej na środowisko poprzez obniżenie energochłonności, zużycia zasobów naturalnych lub zmniejszenie emisji szkodliwych substancji [Ottman i in. 2006]. Dotyczą one działalności nastawionej na ochronę środowiska i przyczyniają się do przekształcenia społeczeństwa na bardziej proekologiczne. Ekoinnowacje obejmują wytwarzanie i zastosowanie nowych wyrobów, usług, procesów, systemów i procedur w celu zaspokojenia potrzeb ludzkich i zapewnienia lepszej jakości życia przy jednoczesnej minimalizacji zużycia zasobów naturalnych oraz emisji zanieczyszczeń do środowiska na jednostkę wyrobu lub usługi w całym cyklu życia w porównaniu z rozwiązaniami alternatywnymi [Kemp, Pearson 2008; Carley, Spapens 2000].

Innowacje ekologiczne są obecnie jednym z ważniejszych czynników rozwoju Unii Europejskiej i równocześnie jednym z ważniejszych obszarów wspieranych przez jej politykę. Wynika to ze strategii „Europa 2020” [Europa 2020... 2010], gdzie wymienia się trzy priorytety działań: rozwój oparty na wiedzy i innowacji (rozwój inteligentny), rozwój oparty na efektywnym korzystaniu z zasobów i przyjazny środowisku (rozwój zrównoważony) oraz rozwój wspierający działania na rzecz wysokiego poziomu zatrudnienia oraz ograniczający ubóstwo (rozwój sprzyjający włączeniu społecznemu) [Pakulska, Rutkowska 2017].

\section{Wskaźnik ekoinnowacyjności}

Pomiar ekoinnowacyjności gospodarek narodowych jest zadaniem trudniejszym od zmierzenia ich ogólnej innowacyjności. W Unii Europejskiej analiza ekoinnowacyjności prowadzona jest od 2010 r. przez departament Komisji Europejskiej odpowiedzialny za politykę ekologiczną (Generalna Dyrekcja ds. Środowiska). W wyniku tych analiz powstaje Eco-Innovation Scoreboard (Eco-IS) o średniej wynoszącej 100. Eco-IS pokazuje jak bardzo poziom innowacji ekologicznych w krajach członkowskich różni się od średniej dla UE, wskazując przy tym mocne i słabe strony każdego z państw [Pakulska 2018].

Wskaźnik Eco-IS ma na celu całościowe spojrzenie na wyniki gospodarcze, środowiskowe i społeczne. Jest on wskaźnikiem syntetycznym, na który składa się obecnie 16 różnorodnych wskaźników podzielonych na 5 grup obrazujących różne wymiary ekoinnowacji (tab. 1). Dzięki takiemu ukształtowaniu indeksu można przedstawić różne aspekty ekoinnowacyjności (więcej na ten temat można przeczytać w [Pakulska 2018]). 
Tabela 1. Wskaźniki składające się na Eco-Innovation Index

\begin{tabular}{|c|}
\hline WSKAŹNIKI BEZPOŚREDNIO ODNOSZĄCE SIĘ DO EKOINNOWACJI \\
\hline $\begin{array}{c}\text { NAKŁADY NA EKOINNOWACJE } \\
\text { Wielkość rządowych wydatków na środowiskowe i energetyczne B+R } \\
\text { Liczba pracowników i badaczy B+R } \\
\text { Wielkość zielonych inwestycji }\end{array}$ \\
\hline $\begin{array}{c}\text { EKOINOWACJE - DZIAEANIA } \\
\text { Liczba firm wprowadzających ekoinnowacje poprawiające } \\
\text { efektywność materiałową na jednostkę produkcji } \\
\text { Liczba firm wprowadzających ekoinnowacje poprawiające } \\
\text { efektywność energetyczną na jednostkę produkcji } \\
\text { Liczba firm posiadających certyfikat ISO } 14001\end{array}$ \\
\hline $\begin{array}{c}\text { EKOINNOWACJE - WYNIKI } \\
\text { Liczba patentów związanych z ekoinnowacjami } \\
\text { Liczba publikacji naukowych związanych z ekoinnowacjami } \\
\text { Informacja w mediach na temat ekoinnowacji }\end{array}$ \\
\hline WSKAŹNIKI ODNOSZĄCE SIĘ DO EFEKTÓW WPROWADZANIA EKOINNOWACJI \\
\hline $\begin{array}{l}\text { EFEKTY DLA ŚRODOWISKA } \\
\text { Produktywność materiałowa } \\
\text { Produktywność wody } \\
\text { Produktywność energii } \\
\text { Emisja gazów cieplarnianych }\end{array}$ \\
\hline $\begin{array}{c}\text { EFEKTY SPOEECZNO-GOSPODARCZE } \\
\text { Eksport produktów ekoprzemysłu } \\
\text { Zatrudnienie w ekoprzemyśle i gospodarce obiegu zamkniętego } \\
\text { Dochód w ekoprzemyśle i gospodarce obiegu zamkniętego }\end{array}$ \\
\hline
\end{tabular}

Źródło: opracowanie własne na podstawie: [European Commission 2018].

\section{Innowacje ekologiczne w krajach Unii Europejskiej}

Poziom ekoinnowacji w krajach członkowskich Unii Europejskiej wykazuje duże zróżnicowanie. Co prawda zróżnicowanie to ulega zmniejszeniu [Pakulska 2018; Pakulska, Rutkowska 2018], jednak trudno stwierdzić, czy będzie to stała tendencja. Na podstawie wskaźnika Eco-IS dzieli się kraje Unii Europejskiej na trzy grupy [Węgrzyn 2013]:

1) Liderzy ekoinnowacji (wartość wskaźnika powyżej 120;

2) Zwolennicy ekoinnowacji (wartość wskaźnika 81-119);

3) Kraje nadrabiające zaległości w zakresie ekoinnowacji (wartość wskaźnika poniżej 80).

Wskaźnik Eco-IS dla poszczególnych krajów plasuje się w przedziale od około 40 do prawie 190 (rys. 1). Należy zwrócić uwagę na fakt, że najliczniejsze w 2010 r. były kraje nadrabiające zaległości w zakresie ekoinnowacji (14), w latach 2011, 2012, 2015, 2016 i 2017 - zwolennicy ekoinnowacji (odpowiednio 11, 12, 13, 17, 14 


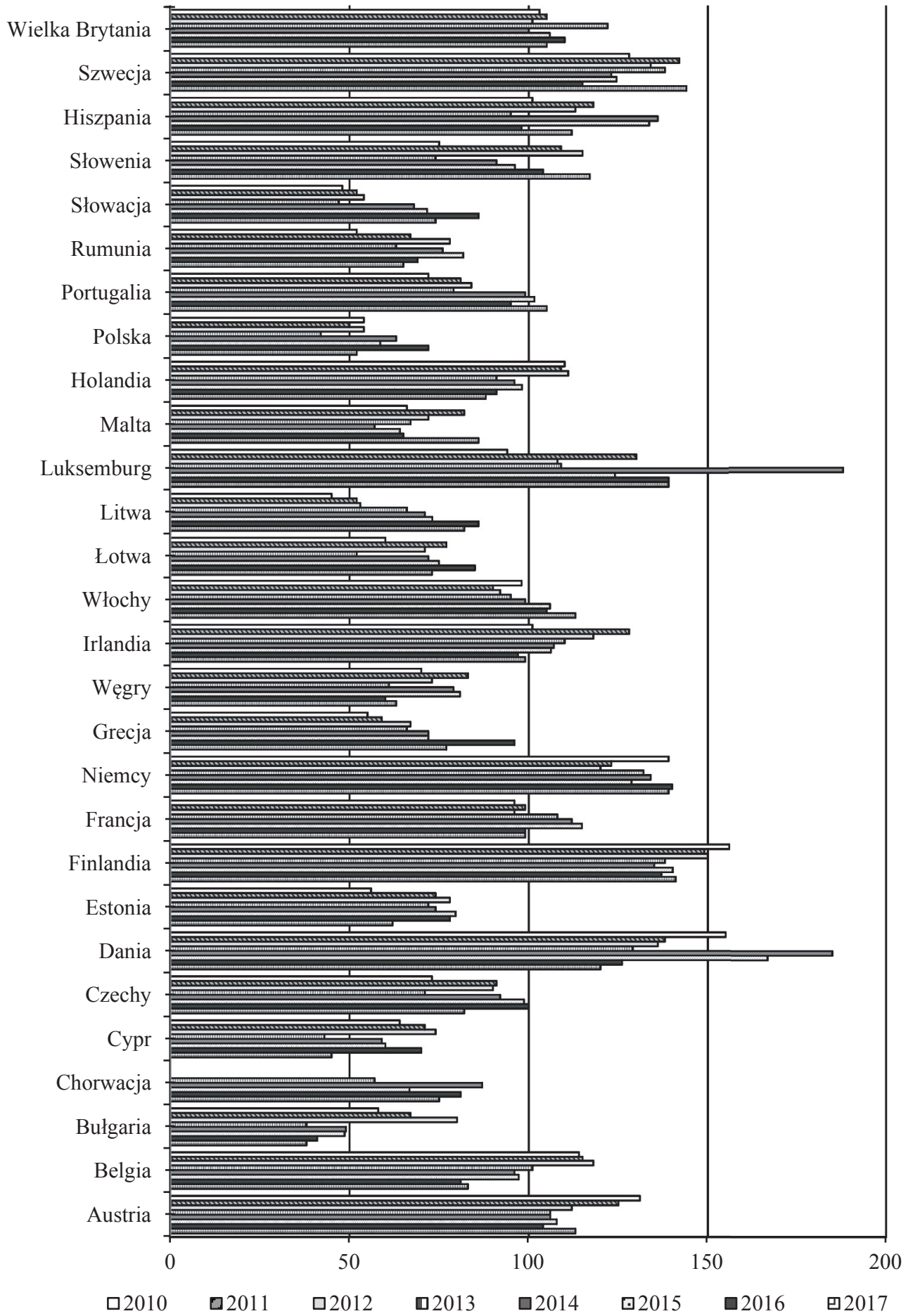

Rys. 1. Wskaźnik Eco-IS w latach 2010-2017

Źródło: opracowanie własne na podstawie: [European Commission 2018]. 
krajów), w 2013 r. najwięcej było krajów nadrabiających zaległości w zakresie ekoinnowacji (15 krajów), natomiast w 2014 r. liczba zwolenników i nadrabiających innowacje była jednakowa (11). W badanym okresie Polska była zaliczana do grupy państw nadrabiających zaległości w zakresie ekoinnowacji i zajmowała jedną z najniższych pozycji w rankingu.

Do grupy liderów ekoinnowacji na przestrzeni lat należały zazwyczaj te same kraje, a jeśli któryś z nich nie znalazł się w danym roku w grupie najbardziej ekoinnowacyjnych krajów, jego wskaźnik niewiele odbiegał od pozycji liderów. Do 2013 r. najwyższym poziomem ekoinnowacyjności charakteryzowała się Finlandia, która również w późniejszych latach zajmowała czołowe lokaty. Oprócz Finlandii w grupie liderów zawsze znajdowały się jedynie Niemcy i Dania. W 2016 r. grupę liderów opuściła Szwecja, która z wynikiem 115 znalazła się na pierwszej pozycji za liderami. Warto także zwrócić uwagę na Luksemburg, który w 2010 r. z wynikiem 94 znajdował się na ostatnim miejscu wśród grupy krajów - zwolenników ekoinnowacji, w późniejszych latach jednak stopniowo i systematycznie poprawiał swój wynik i w 2014 r. zajął pozycję lidera rankingu, w kolejnych latach natomiast zajmował pewne miejsce $w$ gronie liderów ekoinnowacji.

$\mathrm{Na}$ przeciwległym biegunie rankingu, $\mathrm{z}$ bardzo niskim poziomem ekoinnowacyjności na tle pozostałych krajów UE, również w większości przypadków znajdują się te same kraje. Polska na stałe zagościła na dole tabeli z wynikiem około połowy średniej dla UE. W 2012 r. na ostatnim miejscu znalazła się Litwa, która końcowe miejsca w rankingu opuściła na stałe w $2013 \mathrm{r}$. i od tej pory plasuje się w połowie stawki krajów nadrabiających zaległości. Podobnie Grecja, która do 2012 r. zajmowała 4. miejsce od końca, ale już od 2013 r. zajęła podobną pozycję jak Litwa. Odwrotna sytuacja występuje w przypadku Bułgarii, która od 2010 r. systematycznie spadała w rankingu, by od 2013 r. zająć na stałe ostatnie miejsce w rankingu, podobnie jak Cypr, który w 2013 r. zajął trzecie miejsce od końca (przed Polską). Stałe miejsce w końcówce rankingu ma także Słowacja, której pozycja nie ulegała większym wahaniom.

\section{Innowacje ekologiczne w Polsce na tle innych krajów Unii Europejskiej}

Polska nie jest krajem o innowacyjnej gospodarce, dotyczy to także innowacyjności ekologicznej. Należy ona do najmniej ekoinnowacyjnych państw w Europie i pozostaje daleko w tyle zarówno za liderami ekoinnowacji, jak i za krajami nadrabiającymi zaległości w zakresie ekoinnowacji. Spośród pięciu grup wskaźników ${ }^{1}$ wyraź-

\footnotetext{
${ }^{1}$ Trzeba jednak zwrócić uwagę, że wskaźniki te są względne i wzrost lub zmniejszenie wskaźnika nie zawsze świadczy o działaniach danego państwa. Jest on bowiem odniesiony do średniej dla wszystkich krajów, a więc świadczy o poprawie lub pogorszeniu w odniesieniu do innych krajów członkowskich.
} 


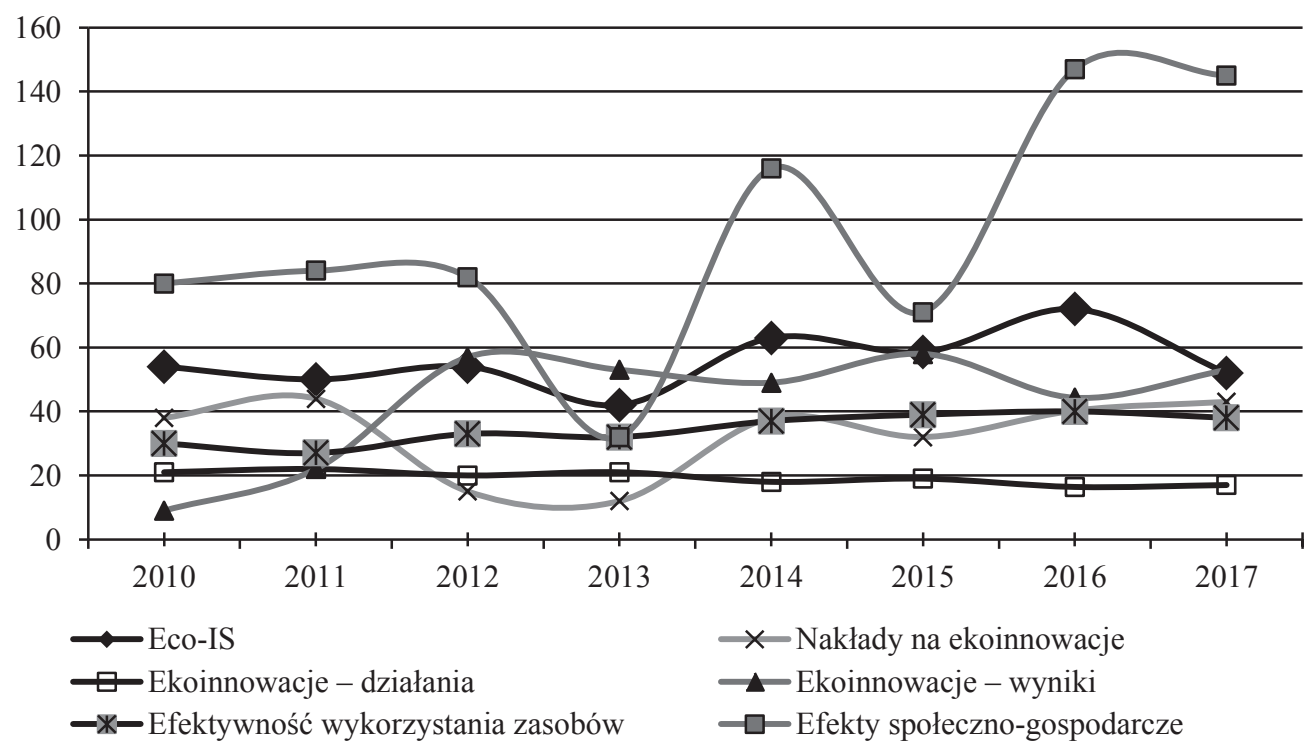

Rys. 2. Wskaźniki ekoinnowacji dla Polski według grup wskaźników w latach 2010-2017

Źródło: opracowanie własne na podstawie: [European Commission 2018].

nie widać, że poprawie ulega obszar efektów społeczno-gospodarczych. Pomimo spadku wskaźnika w latach 2013 i 2015 w kolejnych latach osiąga on coraz wyższy poziom, przekraczając nawet średnią UE (rys. 2). Jest to jednak jedyny obszar, w którym notujemy tak dobre wyniki. W obszarze wyników obserwujemy także systematyczną poprawę wskaźnika, a spadki w niektórych latach nie są głębokie, jednak osiągnięty poziom jest dalece niezadowalający (ok. 50\% średniej UE). Podobnie pozytywny trend obserwujemy w obszarze efektów dla środowiska, gdzie wskaźnik systematycznie i bez żadnych wahań rośnie, ale wzrost ten jest zdecydowanie zbyt wolny i w 2017 r. osiąga ok. 40\% średniej UE. Podobnie w przypadku efektów dla środowiska obserwujemy powolny i systematyczny wzrost do poziomu ok. 40\% średniej UE. Nakłady na ekoinnowacje wahają się i widać raczej tendencję spadkową. Działania na rzecz ekoinnowacji utrzymują się na stałym, bardzo niskim poziomie (ok. 20\% średniej UE). Widać więc, że w zdecydowanej większości obszarów poziom naszego zaangażowania na rzecz ekoinnowacji jest zbyt mały.

\subsection{Nakłady na ekoinnowacje}

W obszarze nakładów na ekoinnowacje większość wskaźników ulega znacznym wahaniom (rys. 3), jednak w większości przypadków osiągają poziom znacznie poniżej poziomu indeksu ogółem. Na bardzo niskim poziomie pozostaje wielkość zielonych 


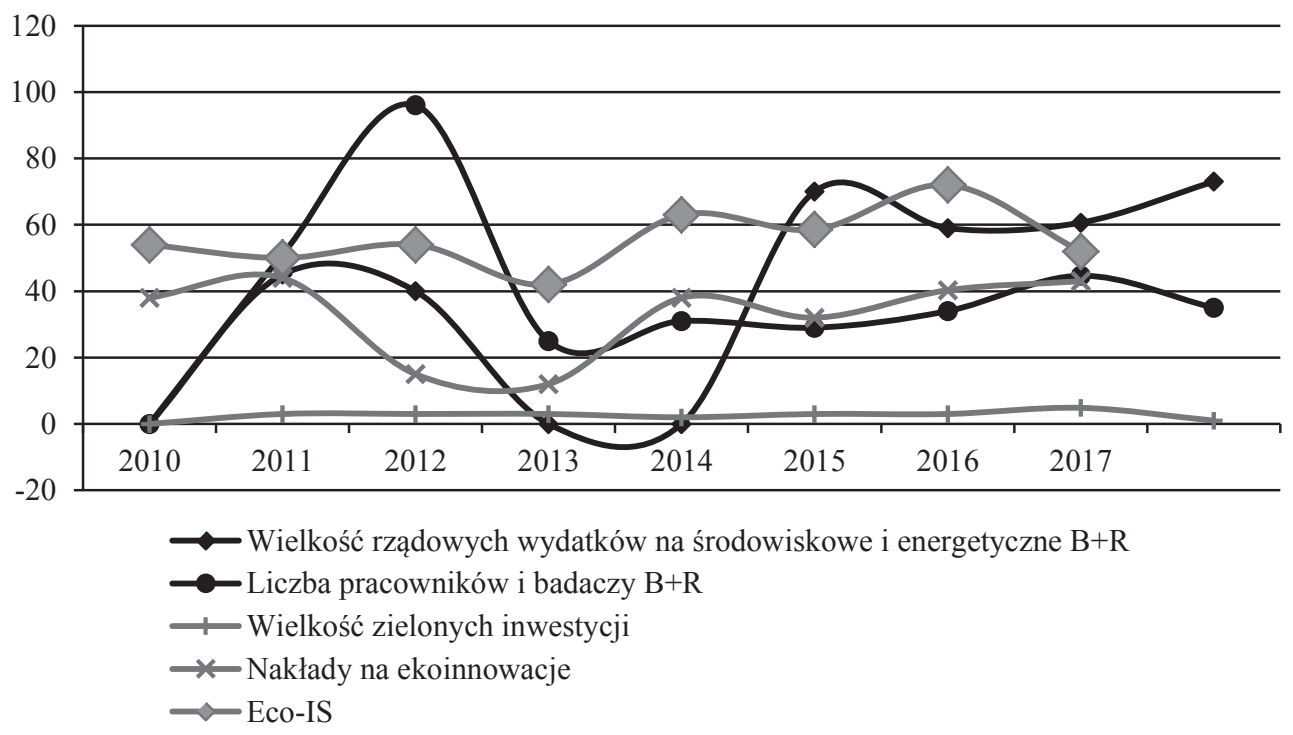

Przerwy w wykresie oznaczają lata, w których nie ma danych.

Rys. 3. Wskaźnik nakładów na ekoinnowacje oraz wskaźniki cząstkowe dla Polski w latach 2010-2017 Źródło: opracowanie własne na podstawie: [European Commission 2018].

inwestycji (poziom wskazuje praktycznie na brak takich inwestycji). Nieco poprawiła się wielkość rządowych wydatków na $\mathrm{B}+\mathrm{R}$. Trudno wytłumaczalny jest gwałtowny wzrost liczby pracowników i badaczy w tym obszarze w 2011 r., ale pomijając ten rok, można zaobserwować systematyczny wzrost, jednak pomimo wzrostu ich liczby w dalszym ciągu jest ich niewielu, gdyż wskaźnik osiąga jedynie ok. 40\% średniej UE. W zakresie nakładów na inwestycje są więc w naszym kraju duże rezerwy. Wspieranie zielonych inwestycji z pewnością jest pierwszym obszarem, który mógłby przynieść poprawę pozycji Polski.

\subsection{Działania w zakresie ekoinnowacji}

W obszarze działań wszystkie wskaźniki w całym badanym okresie są znacznie poniżej indeksu ogólnego i właściwie wszystkie na przestrzeni lat albo utrzymują się na stałym poziomie lub nawet spadają (rys. 4). W tym zakresie konieczne są intensywne działania, np. warto rozważyć wsparcie dla firm wdrażających ekoinnowacje w postaci np. preferencyjnych kredytów czy zachęt podatkowych. Posiadanie certyfikatu ISO 14001 mogłoby przynosić firmom dodatkowe korzyści, np. w postaci preferowania ich w procedurze zamówieniach publicznych. 


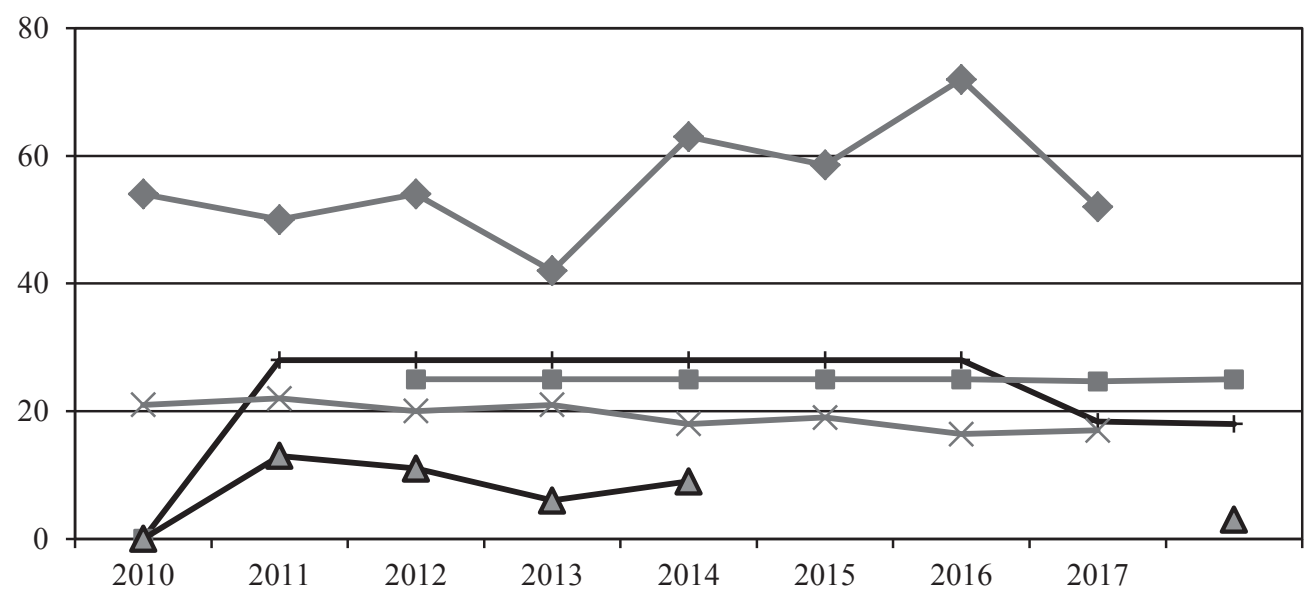

Liczba firm wprowadzających ekoinnowacje poprawiające efektywność materiałową na jednostkę produkcji
- Liczba firm wprowadzających ekoinnowacje poprawiające efektywność energetyczną na jednostkę produkcji
$\rightarrow$ Liczba firm posiadających certyfikat ISO 14001
$\leftarrow$ Ekoinnowacje - działania
$\longrightarrow$ Eco-IS

Przerwy w wykresie oznaczają lata, w których nie ma danych.

Rys. 4. Wskaźniki działań w zakresie ekoinnowacji oraz wskaźniki cząstkowe dla Polski w latach 2010-2017

Źródło: opracowanie własne na podstawie: [European Commission 2018].

\subsection{Wyniki w zakresie ekoinnowacji}

Wskaźnik dotyczący wyników jest na stosunkowo dobrym poziomie i systematycznie rośnie (pomimo niewielkich spadków w latach 2014 i 2016) i od 2012 r. utrzymuje się na poziomie ok. 60\% średniej UE (rys. 5). Od 2014 r. (gdy znacznie wzrosła liczba patentów związanych z ekoinnowacjami) możemy zauważyć pozytywne tendencje w tym zakresie. W kolejnych latach wskaźnik ten w dalszym ciągu utrzymuje się na dość przyzwoitym poziomie (w granicach $60 \%$ średniej UE). Systematycznie rośnie liczba publikacji naukowych związanych $\mathrm{z}$ ekoinnowacjami. W mediach $\mathrm{w}$ latach 2011 i 2012 pojawiło się znacząco więcej informacji na ten temat; w kolejnych latach jednak liczba ta spadła. Pomimo dość przyzwoitego poziomu tych wskaźników większość z nich kształtuje się poniżej wskaźnika ogólnego. Wydaje się, że w tym obszarze poprawa nie wymaga dużych nakładów; wystarczy bowiem wspierać publikacje i informacje medialne o innowacjach ekologicznych. Istnieją także możliwości wspierania patentów związanych z ekoinnowacjami np. ze środków Unii Europejskiej (jedno ze źródeł takiego wsparcia zostało opisane w: [Pakulska, Rutkowska 2017]). 


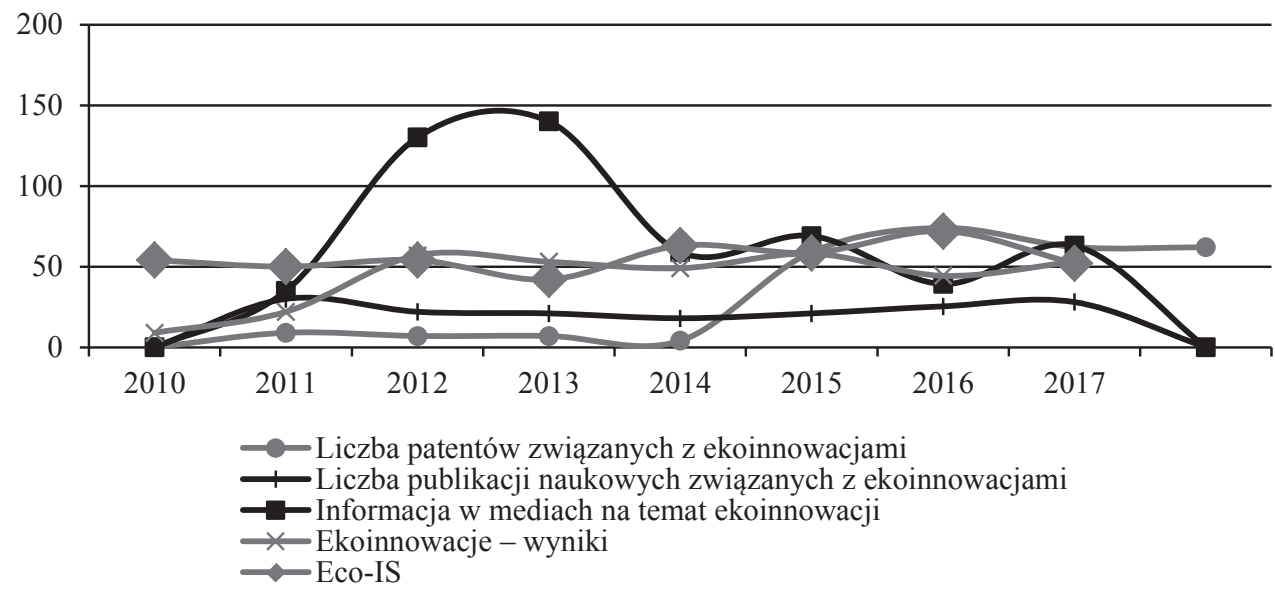

Rys. 5. Wskaźniki wyników w zakresie ekoinnowacji oraz wskaźniki cząstkowe dla Polski w latach 2010-2017

Źródło: opracowanie własne na podstawie: [European Commission 2018].

\subsection{Efekty dla środowiska}

W obszarze efektów dla środowiska większość wskaźników kształtuje się poniżej poziomu indeksu syntetycznego (rys. 6). Systematycznie rośnie produktywność energii, która przekroczyła 70\% średniej UE. Produktywność materiałowa utrzymuje się na niskim,

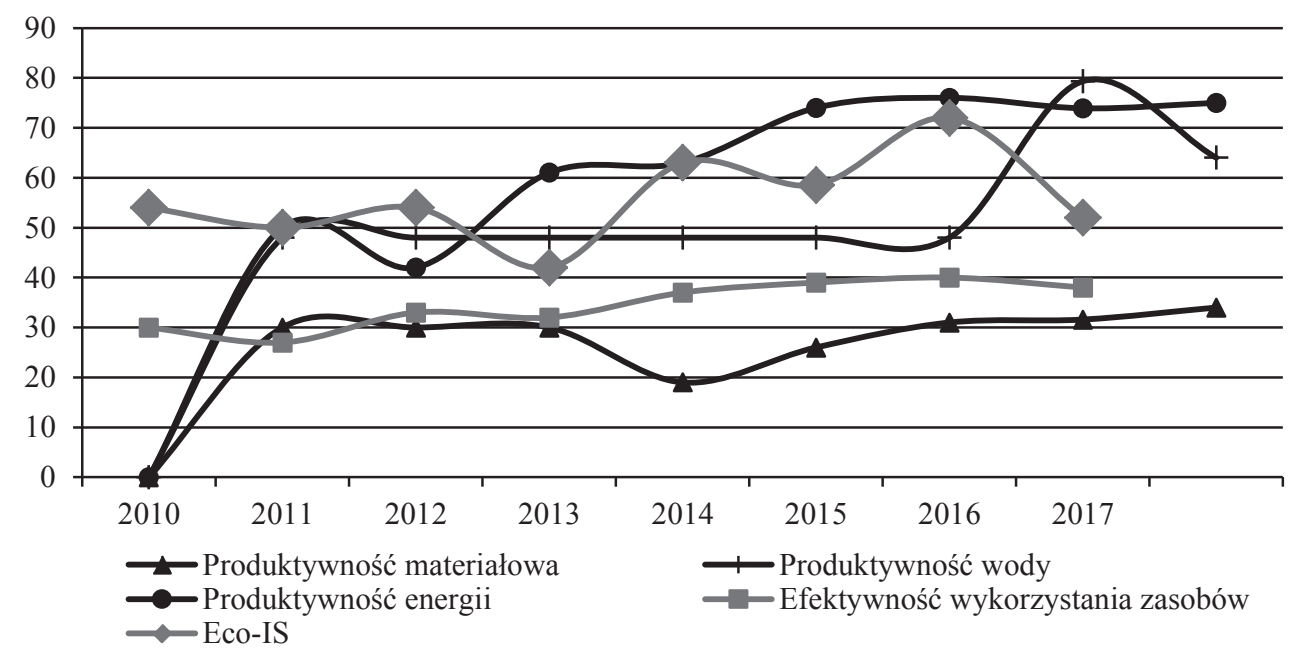

Przerwy w wykresie oznaczają lata, w których nie ma danych.

Rys. 6. Wskaźniki efektów w zakresie ekoinnowacji oraz wskaźniki cząstkowe dla Polski w latach 2010-2017

Źródło: opracowanie własne na podstawie: [European Commission 2018]. 
dość równym, poziomie. Produktywność wody przez długi okres utrzymywała się na stałym poziomie, w 2016 r. gwałtownie wzrosła, by w kolejnym roku ponownie spaść. W tym obszarze wszystkie wskaźniki wymagają podjęcia zdecydowanych działań.

\subsection{Efekty społeczno-gospodarcze}

W obszarze efektów społeczno-gospodarczych większość wskaźników kształtuje się na poziomie wyższym niż ogólny indeks (rys. 7). Eksport produktów ekoprzemysłu systematycznie rośnie i osiągnął w ostatnich latach średni poziom Eco-IS dla Unii Europejskiej. W przypadku zatrudnienia w ekoprzemyśle i gospodarce obiegu zamkniętego trudno znaleźć jakąkolwiek tendencję, gdyż z roku na rok zanotowano znaczne wahania. Dochód w tych branżach, poza spadkiem w 2014 r., systematycznie i znacząco rośnie, już w 2015 r. przekraczając średnią dla UE. Wskaźniki w tym obszarze wskazują, że nie wymaga on pilnych działań.

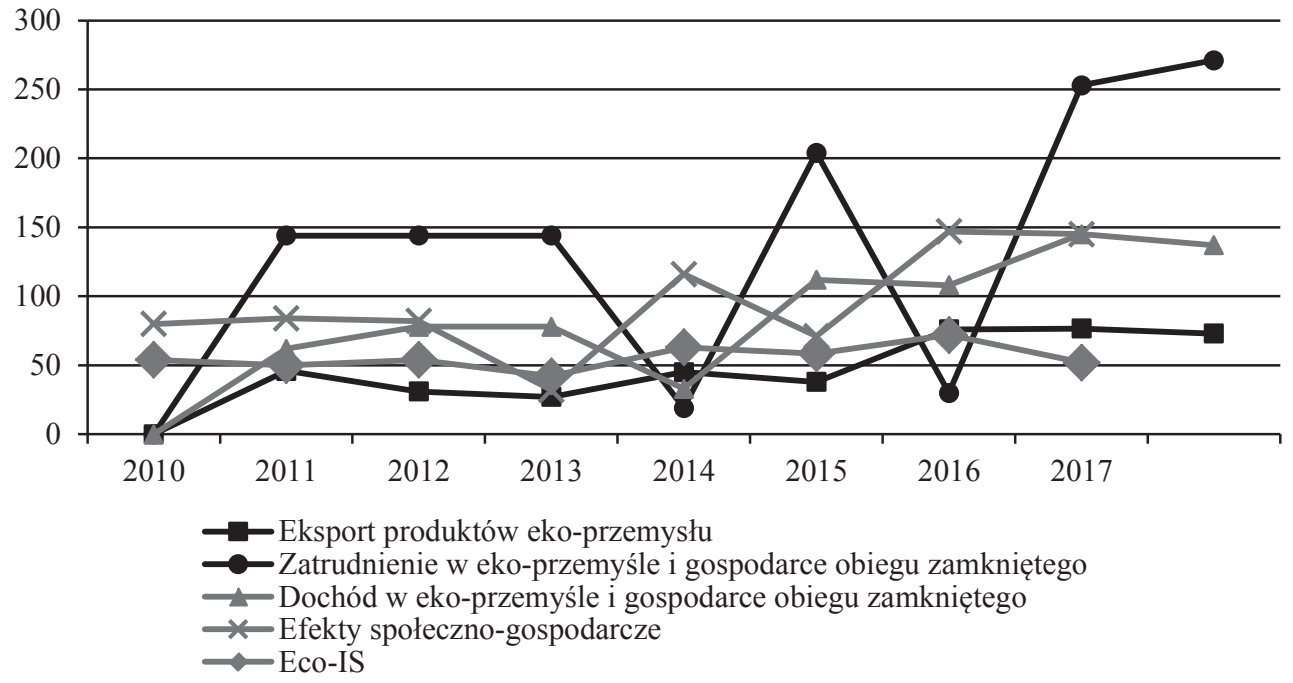

Rys. 7. Wskaźniki efektów społeczno-gospodarczych w zakresie ekoinnowacji oraz wskaźniki cząstkowe dla Polski w latach 2010-2017

Źródło: opracowanie własne na podstawie: [European Commission 2018].

\section{Zakończenie}

Ekoinnowacje są podstawą nowego modelu rozwoju i są bardzo istotne z punktu widzenia ochrony środowiska. Innowacje te służą wspieraniu ochrony środowiska lub przywracaniu go do stanu naturalnego. Stąd też ich rozwój jest niezbędnym ,narzędziem" do trwałego zmniejszenia presji człowieka na środowisko i efektywniejszego wykorzystania kurczących się zasobów środowiska. Wskazuje się, że obecnie nie jest możliwe skuteczne rozwiązanie narastających problemów ekologicznych bez wdrożenia do gospodarki ekoinnowacji. 
Ekoinnowacje łączą w sobie innowacje oraz ochronę środowiska, są więc odpowiedzią na stale rosnące zainteresowanie problematyką ekologiczną. Innowacje w tym zakresie pozwalają na lepszą ochronę środowiska za pomocą coraz lepszych technologii. Czyste środowisko oraz konkurencyjna gospodarka, na rzecz których działają ekoinnowacje, przyczyniają się do podniesienia jakości życia. Jak stwierdza P. Drucker, szansę rozwoju ekoinnowacji stanowią zmiany w sektorze przemysłu oraz nowa wiedza.

Polska innowacyjność ekologiczna na tle krajów Unii Europejskiej wypada dość słabo, dlatego też istotne jest, aby dążyć do wdrażania takich przedsięwzięć, które będą impulsem do poprawy naszej ekoinnowacyjności. Każde państwo UE powinno promować i zachęcać do wprowadzania ekoinnowacyjnych rozwiązań poprzez stosowanie odpowiednich przepisów ustawowych i wykonawczych. Polskie wyniki na tym polu prezentują się bardzo źle, bo Polska jest jednym z najmniej ekoinnowacyjnych krajów w Europie. Ponadto zdecydowana większość polskich wskaźników nie ulega poprawie.

Niski poziom ekoinnowacji w Polsce wynika z ogólnie niskiego poziomu innowacyjności w kraju oraz niskich nakładów na badania i rozwój. Może być on również powiązany z czynnikami strukturalnymi, takimi jak współpraca nauki z przemysłem lub brak zachęt finansowych do wdrażania ekoinnowacji. Na tle innych krajów UE, a zwłaszcza liderów ekoinnowacji, polskie firmy nie posiadają wystarczającego kapitału niezbędnego do wprowadzenia ekoinnowacji. Jest to tym ważniejsze, że ekoinnowacje, podobnie jak ogólnie innowacje, charakteryzują się wysokimi kosztami wdrożenia i wiążą się z wysokim ryzykiem niepowodzenia.

\section{Literatura}

Carley M., Spapens P., 2000, Dzielenie się światem, Wydawnictwo Instytut na rzecz Ekorozwoju, Białystok-Warszawa.

European Commission, 2018, The Eco-innovation Scoreboard and the Eco-innovation Index, https:// ec.europa.eu/environment/ecoap/indicators/index_en (5.05.2018).

Europa 2020. Strategia na rzecz inteligentnego i zrównoważonego rozwoju sprzyjającego włączeniu spolecznemu, 2010, Bruksela.

Kemp R., Pearson P., 2008, Final Report MEI Project about Measuring Eco-innovation, UMMERIT, Maastricht.

Ottman J.A., Strafford E.R., Hartman C.L., 2006, Avoiding green marketing myopia: Ways to improve consumer appeal for environmentally preferable products, Environment: Science and Policy for Sustainable Development, vol. 48, no. 5, s. 22-36.

Pakulska J., 2018, Diversification of eco-innovation in the EU Member States, [w:] Proceedings of the 3rd International Conference on European Integration ICEI 2018, 3rd part, Ostrava, s. 1131-1138.

Pakulska J., Rutkowska M., 2017, Program Inteligentny Rozwój jako wsparcie innowacji ekologicznych $w$ Polsce, Studia i Prace WNEiZ US, t. 3, z. 47, s. 317-326.

Pakulska J., Rutkowska M., 2018, The level of eco-innovations in the EU Member States, [w:] Proceedings of the 3rd International Conference on European Integration 2018, 3rd part, Ostrava, s. 1247-1255.

Schumpeter J.A., 1960, Teoria rozwoju gospodarczego, PWN, Warszawa.

Węgrzyn G., 2013, Ekoinnowacje w Polsce na tle krajów Unii Europejskiej, Ekonomia i Środowisko, nr 3, s. 138-148. 